\title{
TRACES OF FELDGEMEINSCHAFT (FIELD ALLIANCE) IN ROMAN EGYPT LAW SYSTEM AND IN JEWISH LAW
}

\section{Hava Brocha Korzakova}

Bar Ilan University, Classics Department,

Ramat Gan, 5290002, Israel; Chava.Korzakova@biu.ac.il

In P. Oxy. XLI 2954 verso ii.12-25 we find several documents at least two of which discuss the same matter - sale of a property by one side in a partnership. The first document is an edict of the governor of Egypt C. Avidius Heliodorus and the second one is a court decision, apparently from a later date. The governor's decision has no parallel in Roman law; Herrmann and Rupprecht come to the conclusion that it was based on the local Egyptian law, by which neighboring owners have preferential rights to buy a property. More evidence for the presumed Egyptian law is found in a letter from one brother to another, in PSI XII 1259 (= SB V5997) from the second or third century C.E.; and P. Madrid 11 (= SB VI 9621), from the third century C.E., which Youtie sees as additional evidence for this law, in my opinion contradicts it and requires an alternative explanation. Three more documents discussing the same matter are found in $S B$ XIV 12139 from the second century C.E. In each of them we can see additional details of the practice of the law in question under Roman rule in Egypt. It seems that the Egyptian law in question has a parallel in the rabbinic law of dina de-bar mitsra (law of a neighboring owner), which asserts a preferable right of neighbors in buying property (BT Bava Metsia 108a). The common basis of both the Egyptian and the Jewish laws seems to be an archaic Feldgemeinschaft (field alliance). Maybe another level in the development of the same idea is represented by the Greek law concerning the "border-money" (amphourion). An interesting point, as Albeck says, is that the Jewish sources for this law are Babylonian only, which may indicate a deeper influence of the Roman law on the Palestinian Jewish law than on the Babylonian one.

Keywords: Egyptian law, Roman law, Greek law, Jewish law, Juristic papyri, Roman governor of Egypt, Roman Egypt.

In P. Oxy. XLI 2954 verso $\mathrm{ii}^{1}$ we find several documents at least two of which discuss the same matter - sale of a property by one side in a partnership. First document is an edict of the governor of Egypt C. Avidius Heliodorus (presumably from 137 C.E. ${ }^{2}$ ) and the second one is a court decision, apparently from a later date.

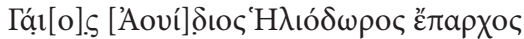

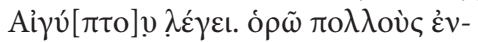

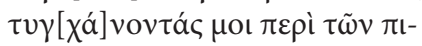

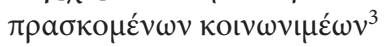

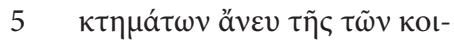

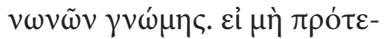

pov $\delta$ ı̀ $\mu \varepsilon \tau \alpha \delta o[\sigma] i ́ \mu \omega \nu \mu \varepsilon \tau \alpha \delta \tilde{\omega}$

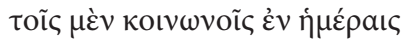

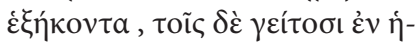

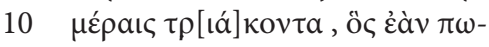

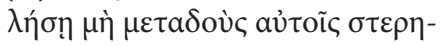

${ }^{1}$ According to R. A. Coles, it is the $3^{\text {rd }}$ column of the papyrus, see The Oxyrhinchos Papyri, 41, 1970, 85; Coles, 1970. See online http://www.trismegistos.org/text/30376.

2 See Coles, 1970.

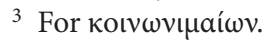

(C) St. Petersburg State University, 2016 


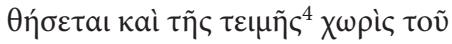

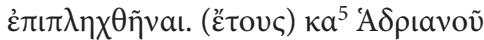

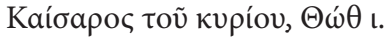

"Gaius Avidius Heliodorus, the prefect of Egypt, says: I see that many people apply to me on the matter of common property sold without asking for the opinion of the co-owners. If previously he (the co-owner) does not pass a message to the co-owners 60 days ahead, and to the neighbors 30 days ahead, if he sells without passing them a message, the money will be taken from him, and he also will be punished. Twenty second year of the rule of the Emperor Hadrianus, Thoth 10."

The first editor of P. Oxy. XLI 2954 Revel A. Coles has noticed two differences between the low practiced in Egypt according to this papyrus and the Roman law:

1. The governor does not mention any difference between common and undivided property (communio pro indiviso) and common but divided property (communio pro diviso) while the second kind of property is not known in the Roman law, ${ }^{6}$ but was in use in Egypt; for the papyrologic evidences see Egon Weiss ${ }^{7}$ and Rafael Taubenschlag. ${ }^{8}$ Subsequently, Johannes Herrmann ${ }^{9}$ and Hans-Albert Rupprecht ${ }^{10}$ came to the conclusion that this decision was based not on the Roman but on the local Greek-Egyptian law, and wrote extensive articles on the subject. I see no need to discuss it here, ${ }^{11}$ but I would like to mention the fact that it is a fine example of a difference between the Roman and the local Greek-Egyptian law while the prefect decides according to the last.

2. The second point mentioned by Revel A. Coles is that in the Roman law there was no rule for neighboring owners to have preferential rights to buy a property, but Avidius Heliodoros says that not only the co-owners but also the neighbors are to be noticed 30 days ahead before the sale, otherwise the sale will be invalid (1l. 7-13). As in the previous example, this order seems to be based on the local law. The time periods mentioned are reasonable: if during the first month following the announcement the co-owners did not come to the agreement, there is no point to pass the message about it to the neighbors.

More evidence for the presumed local law is found in a letter from one brother to another, in PSI XII 1259, 11. 4-12 (= SB V 7997 $\left.{ }^{12}\right)$, from the second or third century C. E.:

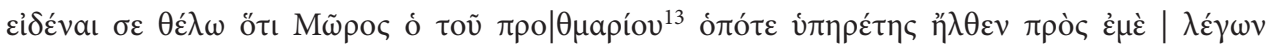

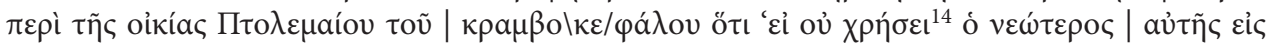

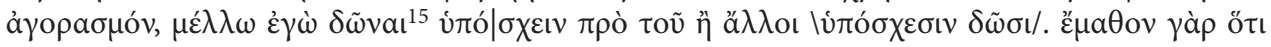

${ }^{4}$ For $\tau \iota \mu \tilde{\eta} \varsigma$.

${ }^{5}$ For $\kappa \beta$, see Coles, 1970.

6 See Taubenschlag 1955, 240.

7 See Weiss 1908, 330-365.

8 See Taubenschlag 1955, 239-243; idem., 1959, 355-356.

9 See Herrmann 1975, 260-266.

10 See Rupprecht 1983, 289-342.

11 See Korzakova 2002, 199-200, 34.

12 See online: http://www.trismegistos.org/text/27174.

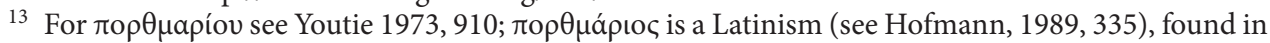
several papyri and in a ostracon: P. Oxy. XXIV 2421, 1. 8 (IV cent. C. E.); P. Merton 42, 1. 4 (V cent. C. E.), see note there; P. Oxy. XVIII 2195, 1. 73 (VI cent. C. E.); O. Amst. 28, 1.6 (II cent. C. E.).

14 For $\chi<\omega>\rho \eta ́ \sigma \varepsilon$.

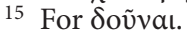




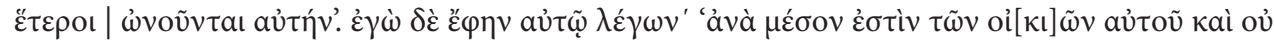

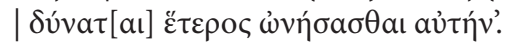

"I wish you to know that Moros, the ferryman's son, the former assistant, ${ }^{16}$ came to me saying regarding the house of Ptolemaeus the Cabbage-head that if your younger (brother) will not hurry with this acquisition, I intent to give an offer, before the others do, since I know that the others are bargaining about it'. And I said to him that 'it is in between his houses, and the others cannot bargain about it"' (1l. 4-12). We do not see here any mention of a law or an edict, and the issue seems to be obvious to writer. ${ }^{17}$

According to Taubenschlag, in PSI 313 (III-IV cent. C. E.) the preferential right of a neighbor to buy a property is called $\pi \rho \omega \tau \varepsilon \dot{\rho} ı$ :

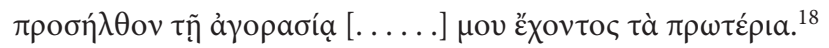

"I come to the sale... while I have a pre-emption right" (1. 3-4). ${ }^{19}$

The same or possibly another variation of this term appears in $B G U 3830$ (I cent. C. E.), reconstructed by the first editor ${ }^{20}$ as $\pi \rho 0 \tau \varepsilon \rho \iota \kappa o ́ v$ and by Olsson (1925) as $\pi \rho \circ \varepsilon \rho[\alpha \tilde{l}(?)]$ $v(?)$ :

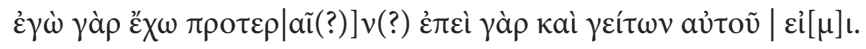

«... For I have the pre-emption right since I am one of his neighbors» (1. 20-22).

Although it is impossible to establish the exact term, it is clear that it is derived of $\pi \rho$ ó $\tau$,, «the first», may be in a comparative form.

Raymond Westbrook ${ }^{21}$ does not mention any similar phenomena in ancient Near East law systems, but the discussed local law in Roman Egypt has a parallel in the Jewish law of dina de-bar mitsra (literally "law of the neighbor", i.e. pre-emption right), which asserts a preferable right of neighbors in buying property. ${ }^{22}$ It is not formulated anywhere in the Jewish sources directly, and we have only a description of the possible situations related to it in Babylonian Talmud, mostly in Bava Metsia 108a-b (and Yalkut Shimoni referring to it), and also in Bava Metsia 68a, Bava Kama 114a, Ketubot 44a, and Bava Batra 5a (see the Appendix), then in the Responsa of the Gaons, and then in the works of the later commentators of those texts. It is not a law de-Orayta (derived from the text of Torah) but a rule (takanat khahamim, i.e. "a rule established by the sages") based on the moral principle 'And thou shalt do that which is right and good in the sight of the Lord'23. It means that the pre-emption right is understood as a natural «right thing to do» which may suggest that this rule is actually very ancient.

16 According to Youtie 1973, 895. Michael Pozdnev suggests «the former servant of the ferryman» (personal communication); he also suggests that Moros here probably is not a proper name but a nickname, «Fool».

17 Youtie suggests that P. Madrid 11 (= SB VI 9621) is also related to the same matter, but there is no evidence in it which would indicate that the property in question is neighboring one, so it seems to be irrelevant here; see Youtie 1967, 384-390. See also Korzakova 2002, 202-203.

18 See Taubenschlag 1955, 320 n. 6; the term suggested by Taubenschlag is hapax legomenon, see PSI

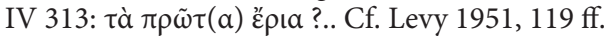

19 See Pringsheim 1950, 280 n. 9.

20 Zereteli 1903; see online: http://www.trismegistos.org/text/25638.

21 Westbrook 2003.

22 See Elon 1994, vol. 2, 625-626.

23 Deuteronomy 6:18. 
One of the differences between C. Avidius Heliodoros's edict and the Jewish «Law of the neighbor» is that in the latter there is no sanction on the seller, and the only part which may suffer the consequences of breaking it is the buyer who may lose his opportunity to purchase the particular plot of land; the time within which the seller must inform the neighbors is not mentioned either. C. Avidius Heliodoros does not say directly whether the sale should be cancelled or not, but we can assume it should, since the pre-emption right is mentioned as obvious one in the other documents. A case of this kind could be brought to the court only if one of the neighbors or co-owners disagreed with the sale and wanted to buy the property in question himself. If so, the decision of C. Avidius Heliodoros means that not only the sale will be cancelled but the seller also will be punished, most probably by a fine.

Another difference between the Talmudic rule and the Greek-Egyptian one is that the Jewish sages discuss some exceptions from the rule, such as in case where the land was sold to a woman or an orphan, which means that it would be very uncomfortable for the buyer to cancel the acquisition, and if so, the Biblical rule 'And thou shalt do that which is right and good in the sight of the Lord' will not be fulfilled. Another case when the fulfillment of the rule is not required is when the sale is much more beneficial for the seller because of the place, the time, or the means of a payment (for the full list of the exceptions see Bava Metsia 108b in the Appendix). In the Greek-Egyptian law, at least as it is represented in the documents we have discussed, we do not see any mention of such exceptions (which does not mean that they could not be present in the actual lawsuits that we have no documents on).

In the Greek law we can see a related idea represented by the law concerning the "boundary-money", as Rafael Taubenschlag formulates it: "The conveyance of real property required a formal act by which the grantor calls upon his neighbors and pays them boundary-money (ả $\mu$ ov́pıov). Thereupon he asked them to make a deposition that he was entitled to sell the property, that he had not sold it to anyone else, before, and to

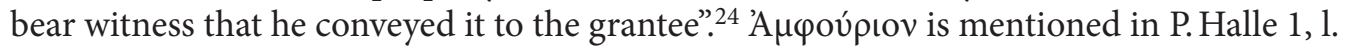
253, from Apollonopolis, Egypt (after 259 B.C.E.) ${ }^{25}$, and in the inscription from Rhodos (200-180 B.C.E.), SEG III, 674, 1. $40^{26}$.

A possible trace of the à $\mu \varphi$ ov́pıov law can be seen in the law from Thurii (South Italy) mentioned by Johannes Stobaeus who quotes Theophrastus (IV-III cent. B. C.E. ${ }^{27}$. First Theophrastus says that in various communities there are various rules concerning a publication of a future property sale, without mentioning any preferential right of the neighbors (though it is interesting that according to him in Athens the seller was obliged to inform the public on his intention to sell the property 60 days before the actual sale, the same period mentioned in the edict discussed regarding the co-owners), he adds (as Stobaeus

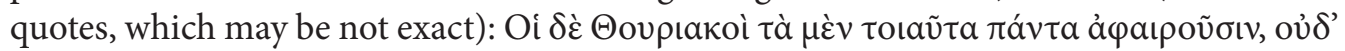

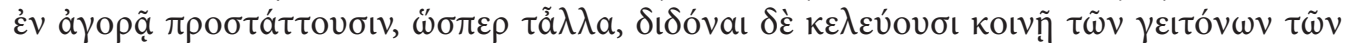

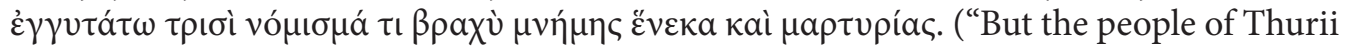
do away all such measures nor do they post a notice in the agora as they do with other

${ }^{24}$ See Taubenschlag 1055, 320-321.

25 See online: http://www.trismegistos.org/text/5876.

26 See also Schwahn 1935, 57-63; Pringsheim 1950, $151 \mathrm{ff}$.

27 Fortenbaugh 1993, 492-495, no. 650 (Anthologium 4.2.20; t. 4 127.20 - 130.26 Hense). The quoted Theophrastus' book on laws among various nations, On contracts, which is now lost. 
things, but they enjoin parties in common to give a small sum of money to the three nearest neighbors so that will remember and give witness.") ${ }^{28}$

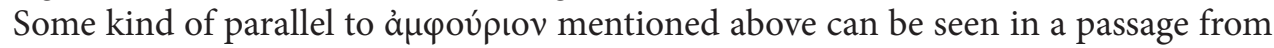
BT Bava Metsia 108a: "What if one came to take counsel of him [sc. the neighbour who enjoys the right of pre-emption] and asked, 'Shall I go and buy it?' and he replied, 'Go and buy it': is mikna (Aramaic for "acquisition", kinyan in Hebrew) from him necessary, or not? - Ravina ruled: No mikna is necessary; the Nehardeans maintained: It is. And the law is that a [formal] acquisition is needed". Mikna (= kinyan) here is an act of formal acquisition of something which is not material (a right to buy in this case); later it was done by holding a material object in the present of witnesses ${ }^{29}$, but there is no specification here, so we cannot know if the neighbor was supposed to receive any money for his consent or not during the Talmudic period. To my opinion, the term mikna (kinyan) may indicate that at least at some early stage this acquisition could be real, i.e. the neighbors indeed were receiving some à $\mu$ oúpıov-like payment, although from the buyer and not from the seller, as we see in the Greek law.

In the Talmudic texts concerning dina de-bar mitsra several rabbis are mentioned, such as Rav (rabbi Aba ben Eivo, or Aba Ariha, ca. 175-247 C. E.), rav Nahman (ca. 250 320 C.E.), rav Ashi (352-427 C.E.), his fellow Ravina, his teacher Amemar, and his son Mar, which points to the dates contemporal or later than those of the Greek documents discussed; we have to keep in mind though that the rabbis used to base their decisions on the previous tradition which is sometimes much older.

An interesting point is that the Jewish sources for this law are Babylonian only (Babylonian Talmud, and then the Responsa of the Gaons). Albeck suggests that in Jewish Palestine the attitude was not as morally high as it did not meet the principle of 'And thou shalt do that which is right and good in the sight of the $\operatorname{Lord}^{30}$, but to my opinion it may also indicate a deeper influence of the Roman law on Palestinian Jewish law than on the Babylonian similar to what was observed for Palestine compared to Egypt ${ }^{31}$. We cannot exclude the possibility that the Greek and the Jewish law could influence each other somewhere in the undocumented past, but if they had not, there is another explanation for their similarity. Rafael Taubenschlag thought that the source for the law concerning à $\mu \varphi$ ov́pıov is an archaic Feldgemeinschaft (field alliance) which had included also the passage right, the irrigation right, etc. ${ }^{32}$ It seems that the remains of this alliance are reflected both in the Greek-Egyptian and the Jewish Babylonian laws concerning the sale of property and the preferential rights of the neighbor in it (but apparently lost from the Jewish Palestinian laws).

The Roman law on servitudes (see Digesta 8, various chapters) reminds of Feldgemeinschaft's consequences, but it's origin is different: the servitudes were established after division of a larger property into smaller units, firstly the communal one into private fields, and then larger plots into smaller ones, when the new smaller units needed certain resources one from another.

\footnotetext{
28 Fortenbaugh, ibid.

29 See Rubinfeld 1992.

30 See Albeck, 'Mizrranut', in: Elon 1975, 231.

31 See Cotton 1993, 94-108.

32 See Taubenschlag 1919-1920, 246 (= idem. 1959, vol. 1, 133-134). See also Rupprecht, op. cit.
} 
If Rafael Taubenschlag's suggestion is correct and the discussed Greek and Roman Egypt laws (and, as I suggest, the Jewish Babylonian law too) are based on Feldgemeinschaft principle, the lack of such a law in the classical Roman system may be explained by the fact that in Rome the private property on land was established at a relatively later stage, being finally standardized by Lex Thoria in 111 B.C.E. ${ }^{33}$ Why the ancient Near East law systems also lack such a law (presented in Raymond Westbrook's book ${ }^{34}$ ), is a matter for another research.

The Jewish sources I have used may need an additional discussion by the specialists who can find the Greek-Egyptian parallel useful. For the reader's convenience I have gathered them here in the Appendix.

\section{Appendix. Dina de-bar mitsra in Babylonian Talmud. ${ }^{35}$}

\section{Bava Metsia 68a:}

Rav Ashi also said: The elders of the town of Mehasia told me, What is the meaning of mashkanta [a pledge]? That it abides with him [the mortagee]. In respect to what has this a practical bearing? - In respect to [the right of] pre-emption.

\section{Bava Metsia 108a-b:}

Rav Judah said in Rav's name: If one takes possession [of an estate lying] between [the fields belonging to] brothers or partners, he is an impudent man, yet cannot be removed. Rav Nahman said: He can even be removed too; but if it is only on account of the right of pre-emption, he cannot be evicted. The Nehardeans said: He is removed even on the score of the right of pre-emption, for it is written, 'And thou shalt do that which is right and good in the sight of the Lord'36. What if one came to take counsel of him [sc. the neighbor who enjoys the right of pre-emption] and asked, 'Shall I go and buy it?' and he replied, 'Go and buy it': is [formal] acquisition from him necessary, or not? - Ravina ruled: No [formal] acquisition is necessary; the Nehardeans maintained: It is. And the law is that a [formal] acquisition is needed. Now that you say that a [formal] acquisition is necessary, - if he did not acquire it of him [and bought the field], it advances or falls in his [the abutting neighbor's] ownership. Now, if he bought it for a hundred $[z u z]$, whereas it is worth two hundred, we see: if he [the original vendor] would have sold it to any one at a reduced figure, he [the abutting neighbor] pays him [the vendee] a hundred $[z u z]$ and takes it. But if not [and it was a special favor to the vendee], he must pay him two hundred and only then take it. But if he bought it for two hundred, its value being only one hundred, - it was [at first] thought that he [the abutting neighbor] can say to him, 'I sent you for my benefit, not for my hurt.' But Mar Kashisha, the son of rav Hisda, said to rav Ashi: Thus did the Nehardeans say in rav Nahman's name: There is no law of fraudulent purchase in respect to real estate.

\footnotetext{
33 Appian, De bello civili 1, 27.

34 See Westbrook, op. cit.

35 The translation is based on Soncino Talmud (Babylonian Talmud, ed. by I. Epstein, London, 19351952), with some alterations.

36 Deuteronomy 4:18.
} 
If one sold a griva ${ }^{37}$ of land in the middle of his estate, we see: if it is of the choicest or of the most inferior quality, the sale is valid; otherwise it is mere evasion.

A gift is not subject to the law of pre-emption. Said Amemar: But if he [the donor] promised security of tenure, it is subject thereto. When one sells all his property to one person, the law of pre-emption does not apply.

[Likewise, if it is sold] to its original owner, it is not subject to the law of pre-emption. If one purchases from or sells to a heathen, there is no law of pre-emption. 'If one purchases from a heathen' - because he [the purchaser] can say to him [the abutting neighbor], 'I have driven away a lion from your boundaries.' 'If he sells to a heathen' - because a heathen is certainly not subject to [the exhortation], 'And thou shalt do that which is right and good in the sight of the Lord.' Nevertheless, he [the vendor] is placed under a ban, until he accepts responsibility for any injury that might ensue through him [the heathen]. A mortgage is not subject to the law of pre-emption. For rav Ashi said: The elders of Matha Mehasia told me, What is the meaning of mashkanta [a pledge, mortgage]? That it abides with him [the mortgagee]. What is its practical bearing? In respect to pre-emption.

When one sells [an estate] that is far [from the vendor's domicile] in order to buy one that is near, or an inferior property to repurchase a better, the law of pre-emption does not apply.

[When an estate is sold] for poll-tax, alimony [of a widow and her daughters] and funeral expenses, the law of pre-emption does not apply, for the Nehardeans said: For poll-tax, alimony, and funeral expenses an estate is sold without public announcement.

[A sale] to a woman, orphans, or a partner is not subject to the law of pre-emption. Of urban neighbors and rural neighbors, the former have priority; of a neighbor [but not of the field to be sold] and a scholar, the latter takes precedence; of a relative and a scholar, the latter has priority. The scholars propounded: What of a neighbor and a relative? Come and hear: Better is a neighbor that is near than a brother that is far off. ${ }^{38}$

If one offers well-formed coins, and the other full - weight coins, the law of preemption does not apply. If these [the coins of the abutting neighbor] are bound up, and those [of the purchaser] unsealed, there is no pre-emption. If he [the neighbor] says, 'I will go, take trouble, and bring money;' we do not wait for him. But if he says, 'I will go and bring money;' we consider: if he is a man of substance, who can go and bring the money [without delay], we wait for him; if not, we do not wait for him.

If the land belongs to one and the buildings [upon it] to another, the former can restrain the latter, but the latter cannot restrain the former. If the land belongs to one and the palm-trees [upon it] to another, the former can restrain the latter, but the latter cannot restrain the former. [If a stranger wishes to purchase] the land for building houses, and [the abutting neighbor wants] the land for sowing, habitation is more important; and there is no law of pre-emption. If a rocky ridge or a plantation of young palm trees lay between [the fields], we consider: If he [the abutting neighbor] can enter therein even with a single furrow, it is subject to the law of pre-emption, but not otherwise.

If one of four neighbors [on the four sides of a field] forestalled the others, the sale is valid; but if they all come together, it [the field] is divided diagonally.

\footnotetext{
$37519.84 \mathrm{~m}^{3}$.

38 Proverbs 27:10.
} 
It is obvious [that the reason why both deeds are valid where] the first [was a deed] of sale and the second [a deed] of gift [is because the action of the owner] was intended to improve the other's rights, as a safeguard against the law of pre-emption; and much more [is this obvious where] the first was for a gift and the second for a sale, for it may then be presumed that the latter was written in that manner in order to safeguard the other against a creditor's rights.

\section{Bava Kama 114a:}

Rav Ashi further said: A son of Israel who sells to a heathen a field bordering on one of a fellow Israelite deserves to have a shamta (lit. 'desolation'; a ban, or excommunication) pronounced against him. For what reason? If because of the right of [pre-emption enjoyed by] the nearest neighbor to the boundary, did the Master not state that where he buys from a heathen or sells to a heathen the right of [pre-emption enjoyed by] the nearest neighbor to the boundary does not apply? - It must therefore be because the neighbor might say to the vendor: 'You have placed a lion at my border. ${ }^{39} \mathrm{He}$ therefore deserves to have a shamta pronounced against him unless he accepts upon himself the responsibility for any consequent mishap that might result [from the sale].

\section{Bava Batra 5a:}

Runya bought a field adjoining a field of Ravina. The latter thought he was entitled to eject him in virtue of his right of preemption. Said rav Safra the son of rav Yeva to Ravina: You know the saying, Four for the large skin, four for the small skin, tslala (or: Four for the skin, four for the tanner, tsalala)..$^{40}$

\section{References}

Coles R., The Date of the Commencement of the Prefecture of Avidius Heliodorus, Proceedings of XII ${ }^{\text {th }}$ International Congress of Papyrology, Ann Arbor, 13-17 August 1968, Toronto, 1975, 85-87.

Cotton H., The guardianship of Jesus son of Babatha: Roman and Local law in the province of Arabia, The Journal of Roman Studies 1993, 83, 94-108.

Elon M. (ed.), The Principles of Jewish Law, Jerusalem, Encyclopaedia Judaica, 1975.

Elon M., Jewish Law: History, Sources, Principles, Philadelphia, Jewish Publication Society, 1994.

Fortenbaugh W. W. et al. (ed.), Theophrastus of Eresus. Sources for his Life, Writings, Thought and Influence. Part 2. Leiden,Brill, 1993.

Funk S., Die Juden in Babylonien, 200 - 500, Berlin, Poppelauer, 1902.

Herrmann J., Zum Edikt des Präfekten Gaius Avidius Heliodorus, Zeitschrift der Savigny-Stiftung für Rechtgeschighte, Romanistiche Abteilung 1975, 92, 260-266.

Hofmann H., Die lateinischen Wörter im Griechischen bis 600 n. Chr., Erlangen, Univ. Erlangen-Nürnberg, 1989.

39 «It was no uncommon practice for the unscrupulous heathen to interfere with the irrigation on which the life of the neighboring fields depended and then force the owners to move out and seek their existence elsewhere», see Funk, 1902, I, 16.

40 I. Epstein in Soncino Talmud translates: "The hide costs four zuzim, and four are for the tanner", and adds a note: "Apparently R. Safra meant that by having two fields instead of one, Ronya, who was a poor man, would save expense, and therefore Rabina ought to let him keep it. But the exact application of the saying here is obscure. v. Rashi and Tosaf". According to another explanation of this obscure proverb, it means "four for a small skin, four for a large skin". In any case, the general meaning of rav Safra's notification to Ravina is clear: the rule is 'And thou shalt do that which is right and good in the sight of the Lord', so Ravina must fulfill it by letting Runya to buy the land in question, since Runya is the poorer one and needs it more. 
Korzakova H. B., Edicts of Roman Prefects of Egypt (PhD Thesis), Ramat Gan, Bar Ilan University, 2002 (Hebrew with English summary), 199-200.

Levy E., West Roman Vulgar Law: The Law of Property, Philadelphia, American Philosophical Society, 1951.

Olsson B. H., Papyrusbriefe aus der frühesten Römerzeit: Inaugural-Dissertation. Uppsala, Almqvist \& Wiksell, 1925.

Pringsheim F., The Greek Law of Sale, Weimar, H. Böhlaus Nachfolger, 1950.

Rubinfeld A., Torat ha-kinyanim (Law of Acquisitions), Jerusalem, 1992 (in Hebrew, ed. by the author).

Rupprecht H.-A., Zu Voraussetzungen, Umfang und Herkunft des Vorkaufrechts der Gemeinschafter nach Papyri, [in:] Symposion 1979. Vorträge zur griechischen und hellenistischen Rechtsgeschichte, Köln, Wien, Böhlau, Verlag, 1983, 289-342.

Schwahn W., AMФOYPION und AMФOҮPIA $\mathrm{MO} \Sigma$, Archiv für Papyrusforschung, 1935, 11, 57-63.

Taubenschlag R., Das Römische Privatrecht zur Zeit Diokletians, Bulletin de l'Academie Polonaise des Scienes et des Lettres, Cracovie, 1919-1920 (Krakau 1923), 141-281.

Taubenschlag R., The Law of Greco-Roman Egypt in the Light of the Papyri, 332 B. C. -640 A. D. (2 $2^{\text {nd }}$ edition), Warzsawa, Panstwowe Wydawnictwo Naukowe, 1955.

Taubenschlag R., Opera minora, Warzsawa, Panstwowe Wydawnictwo Naukowe, 1959.

Weiss E., Communio pro diviso und pro indiviso in den Papyri, Archiv für Papyrusforschung 4, 1908, 330365.

Westbrook R., A History of Ancient Near Eastern Law, Leiden, Brill, 2003.

Youtie H.C., Papyrus Madrid 11 (SB VI 9621), Chronique d'Egypte 1967, 42, 384-390.

Youtie H. C., Linguistic notes in Papyrus texts, in: Scriptunculae, Amsterdam, Hakkert, 1973, 894-895.

For citation: Korzakova H.B. Traces of Feldgemeinschaft (Field Alliance) in Roman Egypt Law System and in Jewish Law. Philologia Classica 2016, 11(2), 244-252. DOI: 10.21638/11701/spbu20.2016.203

\section{СЛЕДЫ FELDGEMEINSCHAFT (ПОЛЕВОГО СОЮЗА) \\ В ЮРИДИЧЕСКОЙ СИСТЕМЕ РИМСКОГО ЕГИПТА И В ЕВРЕЙСКОМ ЗАКОНОДАТЕЛЬСТВЕ}

\section{Хава Броха Корзакова}

P. Oxy. XLI 2954 verso ii.12-25 содержит несколько документов, по меньшей мере два из которых посвящены одной и той же теме - продаже собственности одним из совладельцев. Первый документ представляет собой указ римского наместника Египта Гая Авидия Гелиодора (предположительно от 137 г. н.э.), второй - решение суда, очевидно, более позднее. Указания наместника не имеют параллелей в римском законодательстве; Германн и Руппрехт приходят к выводу, что они основываются на местном египетском законе, согласно которому у соседей есть преимущественное право приобретения собственности. Еще одно свидетельство существования предполагаемого египетского закона находится в письме от брата к брату в PSI XII 1259 (= SB V5997), датируемом вторым или третьим в. н.э.; третий документ, P. Madrid 11 (= SB VI 9621), относящийся к третьему в. н. э., который Юти считает дополнительным свидетельством существования этого закона, по моему мнению, противоречит ему и требует иного объяснения. Три текста, в которых обсуждается эта же тема, находятся в папирусе SB XIV 12139, относящемся ко второму в. н. э. В каждом из них мы можем увидеть дополнительные детали применения обсуждаемого закона в Римском Египте. Представляется, что обсуждаемый египетский закон имеет параллель в талмудическом «Законе о соседе» (дина де-бар миира), согласно которому соседи имеют преимущественное право приобретения собственности (ВТ, Бава Мециа, 108a, см. Elon 1973, 513-514). Представляется, что оба закона, и египетский, и еврейский основываются на понятии архаического Feldgemeinschaft (полевого союза). Возможно, другая стадия развития той же идеи представлена в греческом законе, касающемся «пограничных денег» (амфурион). Любопытно, что, как замечает Албек, еврейские источники этого закона сводятся исключительно к вавилонским, что может указывать на более сильное влияние римского законодательства на палестинское еврейское законодательство, нежели на вавилонское.

Ключевые слова: египетское право, римское право, греческое право, еврейское право, юридические папирусы, римский наместник Египта, римский Египет. 